\title{
21. RADIOLARIANS FROM SEDIMENTS OF THE IZU-BONIN REGION, LEG $126^{1}$
}

\author{
Jonathan C. Aitchison ${ }^{2}$
}

\begin{abstract}
Radiolarians occur at five Leg 126 sites. Well-preserved radiolarians were recovered from Miocene and Pliocene through Holocene sections. The results of this study may help to fill the informational gap on Quaternary radiolarian distribution at mid-latitudes in the western Pacific. Radiolarian preservation is discontinuous, and, although present in Oligocene sections, specimens are poorly preserved.
\end{abstract}

\section{INTRODUCTION}

Siliceous microorganisms are abundant in Quaternary sediments from sites drilled during Ocean Drilling Program (ODP) Leg 126, and their abundance may be related to the availability of silica associated with arc volcanism. Several species that are important for detailed resolution of biostratigraphy in equatorial regions are not present in mid-latitude sediments from the Izu-Bonin region. Leg 126 data will help to fill the informational gap on Quaternary radiolarian distribution at mid-latitudes in the western Pacific.

Moderately well-preserved radiolarian assemblages were recovered from Miocene sections in the Izu-Bonin forearc. Below the Miocene sections, although radiolarians are often abundant, specimens have typically experienced significant dissolution and are not preserved well enough for biostratigraphic analysis.

\section{MATERIAL}

Radiolarians were recovered at Sites 787, 790, 791, 792, and 793. Preservation and abundance are generally good in the Quaternary sections of all sites. Although radiolarians are abundant in some Miocene and Oligocene sections, they are generally poorly preserved.

Site $787\left(32^{\circ} 22.51^{\prime} \mathrm{N}, 140^{\circ} 44.64^{\prime} \mathrm{E}, 3259 \mathrm{~m}\right.$ water depth $)$ is located on the eastern edge of the Izu-Bonin forearc sedimentary basin, about $95 \mathrm{~km}$ east of the arc volcano Aoga Shima and $135 \mathrm{~km}$ west of the axis of the Izu-Bonin Trench (Fig. 1). Quaternary sediments from Site 787 contain abundant radiolarians, with the exception of rare, poorly preserved specimens in Core 126-787B-13R. Identifiable radiolarians are absent below Core 126-787B-5R, although infilled and highly corroded radiolarian ghosts were frequently observed.

Sites $790\left(30^{\circ} 54.96^{\prime} \mathrm{N}, 139^{\circ} 50.66^{\prime} \mathrm{E}, 2223 \mathrm{~m}\right.$ water depth $)$ and 791 $\left(30^{\circ} 54.97{ }^{\prime} \mathrm{N}, 139^{\circ} 52.50^{\prime} \mathrm{E}, 2268 \mathrm{~m}\right.$ water depth) are located near the center of Sumisu Rift, a backarc graben west of the Izu-Bonin island-arc-volcanoes Sumisu Jima and Tori Shima (Fig. 1). Well-preserved radiolarians occur in many samples from Sites 790/791 and have a late Pliocene to Holocene age range. The abundance of radiolarians is variable and they are often diluted by volcanic ash.

Site $792\left(32^{\circ} 23.96^{\prime} \mathrm{N}, 140^{\circ} 22.80^{\prime} \mathrm{E}, 1787 \mathrm{~m}\right.$ water depth $)$ is located on the western half of the Izu-Bonin forearc sedimentary basin, about $60 \mathrm{~km}$ east of the arc-volcano Aoga Shima and $170 \mathrm{~km}$ west of the axis of the Izu-Bonin Trench (Fig. 1). Radiolarians are common to abundant and generally well preserved in Miocene to Quaternary sections of holes drilled at Site 792.

Site $793\left(31^{\circ} 06.33^{\prime} \mathrm{N}, 140^{\circ} 53.27^{\prime} \mathrm{E}, 2964 \mathrm{~m}\right.$ water depth) is located in the center of the Izu-Bonin forearc sedimentary basin, about $70 \mathrm{~km}$

\footnotetext{
${ }^{1}$ Taylor, B., Fujioka, K., et al., 1992. Proc. ODP, Sci. Results, 126: College Station, TX (Ocean Drilling Program).

${ }^{2}$ Department of Geology and Geophysics, University of Sydney, New South Wales 2006, Australia.
}

east of the volcanic front between the islands of Sumisu Jima and Tori Shima and $125 \mathrm{~km}$ west of the axis of the Izu-Bonin Trench (Fig. 1). All core-catcher samples from Hole 793A were examined. Quaternary radiolarians are present in all samples except Samples 126-793A-2H$\mathrm{CC}$ and $-8 \mathrm{H}-\mathrm{CC}$. The occurrence of Druppatractus acquilonius in and below Sample 126-793A-3H, $0 \mathrm{~cm}$, indicates an age $>300$ k.y. for samples at and below this level (Foreman, 1981). Rare, moderately preserved radiolarians are present in samples from Hole 793B in Sample 126-793B-2R-CC and Samples 126-793B-4R-CC through $-8 \mathrm{R}-\mathrm{CC}$. No identifiable faunas were found in, or below, Sample 126-793B-9R-CC. Radiolarians are present in many samples but are typically infilled and have suffered considerable dissolution.

\section{METHODS}

Samples were taken at least every section. Because of the high sedimentation rates and the absence of important equatorial biostratigraphic index species in these mid-latitude sediments, core-catcher samples only were examined at most sites. More detailed examinations, as closely spaced as three per section, were conducted in the vicinity of particular radiolarian events to describe and compare the sites adequately. To obtain clean radiolarian concentrates for microscopic examination, sediments were disaggregated and sieved to remove the clay-silt fraction. A $5-\mathrm{cm}^{3}$ sample was placed in a $400-\mathrm{cm}^{3}$ beaker containing $150 \mathrm{ml}$ of a $10 \%$ solution of hydrogen peroxide and a small amount of calgon (to aid in disaggregating the sediment). If calcareous components were evident, they were dissolved by adding hydrochloric acid. The residue was sieved through a $63-\mu \mathrm{m}$ sieve, and the remaining siliceous microfossils were pipetted evenly onto labeled glass slides. The accompanying water was then evaporated under a heat lamp, after which the remaining residue was mounted using Norland Optical Adhesive and covered with a $22 \times 50 \mathrm{~mm}$ cover slip. Two slides were prepared and examined for each sample. Qualitative assessments of the radiolarians in each slide were recorded for abundance and preservation using the following terms: $\mathrm{C}=$ common, $\mathrm{F}=$ few, $\mathrm{R}=$ rare, and $\mathrm{B}=$ barren for abundance; and $\mathrm{G}=\operatorname{good}, \mathrm{M}=$ moderate, and $\mathrm{P}=$ poor for preservation.

\section{BIOSTRATIGRAPHIC FRAMEWORK}

The Cenozoic radiolarian zonation of Sanfilippo et al. (1985), derived for the tropical equatorial Pacific, was used at all sites. Sanfilippo et al. (1985) summarized the taxonomy and evolutionary lineages of all stratigraphically important radiolarian taxa commonly found in low-latitude regions of this zonation. In suggesting tentative "absolute" ages for radiolarian datum levels and zonal boundaries, the schemes of Nigrini (1985) and Barron et al. (1985), established on the basis of Deep Sea Drilling Project (DSDP) Leg 85 sites in the equatorial Pacific, were followed. Quaternary biostratigraphic data listed by Foreman (1981) were also used. Although much of the 


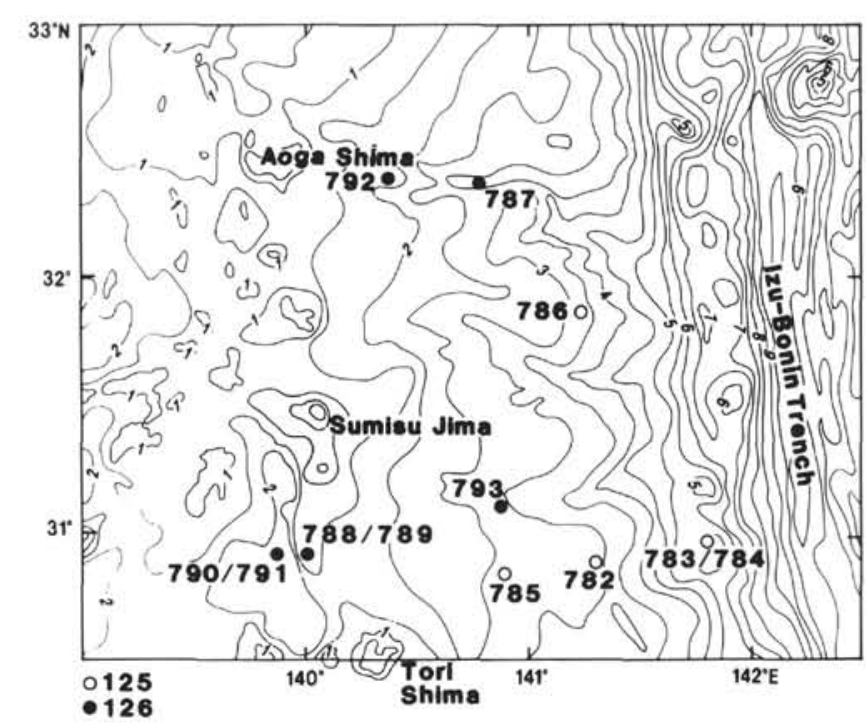

Figure 1. Leg 126 site location map. Bathymetric contours are given every $0.5 \mathrm{~km}$ but are only labeled every $1 \mathrm{~km}$.

material obtained on Leg 85 could not be directly dated paleomagnetically, there were sufficient duplicate sites in which all major microfossil events could be identified, some of which had been correlated to the polarity time scale in nearby piston cores. Thus, the ages of Pacific radiolarian events estimated by Foreman (1981), Nigrini (1985), and Barron et al. (1985) are considered to provide a satisfactory working model.

\section{RESULTS}

\section{Site 787}

Radiolarians are abundant in Quaternary sediments from Site 787. An abundant and well-preserved radiolarian assemblage was recovered from Samples 126-787B-1R-CC through -3R-CC (Table 1). This assemblage contains Lamprocyclas maritalis, Anthocyrtidium angulare, Axoprunum angelinum, Theocorythium trachelium, and Eucyrtidium calvertense and is typical of the Anthocyrtidium angulare Zone of the lower Pleistocene. Younger calcareous nannofossils in these samples indicate possible reworking of radiolarians from slightly older sediments. Sample 126-787B-5R-CC contains a radiolarian assemblage that is diluted by volcanogenic debris. The assemblage includes Diartus hughesi. The occurrence of this species in the assemblage allows assignment to the Didymocyrtis antepenultima Zone in the upper Miocene.

Below Core 126-787B-5R, infilled and highly corroded radiolarian ghosts were frequently observed; however, with the exception of rare, poorly preserved specimens in Core 126-787B-13R identifiable radiolarians were not seen. A single identifiable specimen Lithocyclia angusta was recovered from Sample 126-787B-13R. The specimen is poorly preserved but permits tentative assignment to the Dorcadospyris ateuchus Zone of the upper Oligocene.

\section{Sites 790/791}

Well-preserved radiolarians occur in many samples from Sites $790 / 791$ and are of late Pliocene to Holocene age (Tables 2-6). The abundance of radiolarians is variable, and they are often diluted by volcanic ash. Preservation is generally good. A diverse radiolarian assemblage that includes Didymocyrtis tetrathalamus, Lamprocyclas maritalis maritalis, Theocorythium trachelium dianae, Botryostrobus auritus/australis group, Amphirhopalum ypsilon, Stylochlamydium asteriscus, Eucyrtidium spp., Tetrapyle octacantha, and Spongaster tetras tetras occur in samples from throughout all holes drilled at Sites 790/791. The common occurrence of Theocorythium trachelium dianae indicates a maximum late Pliocene age. Specimens of Druppatractus acquilonius occur in Sample 126-790C$12 \mathrm{X}-\mathrm{CC}$ and in samples below this level. This species was also observed at Site 791 in and below Sample 126-791B-17R-CC. The occurrence of Druppatractus acquilonius indicates an age $>0.3 \mathrm{Ma}$ (Foreman, 1981) for samples deeper than 184.2 mbsf at Site 790 and more than 540.9 mbsf at Site 791. Specimens of Axoprunum angelinum occur in Sample 126-790C-15X-CC. This species was first observed downhole at Site 791 in Sample 126-791B-24R-CC. The last occurrence of Axoprunum angelinum was at $0.41 \mathrm{Ma}$ (Foreman, 1981), and its presence indicates an age greater than this for samples below 213.2 mbsf at Site 790 and below 608.4 mbsf at Site 791. More precise dating using radiolarians was not possible as published Quaternary zonations are based on the occurrence of rare equatorial forms (Sanfilippo et al., 1985) that were not observed at Sites 790/791, which are at middle latitudes.

Radiolarians are generally common to abundant in the samples examined except where diluted by volcanic ash. Preservation is typically moderate to good. Two radiolarian datums were recognized: the last appearance of Druppatractus acquilonius, at $300 \mathrm{Ka}$ and the last appearance of Axoprunum angelinum about $410 \mathrm{Ka}$ (Foreman, 1981). Diatoms and silicoflagellates are also common in many samples.

\section{Site 792}

Radiolarians are common to abundant and generally well preserved in Miocene to Quaternary sections of holes drilled at Site 792 (Tables 7-11). Radiolarians from Hole 792A occur in Samples 126792A-1H-CC, $-3 \mathrm{H}-\mathrm{CC},-4 \mathrm{H}-\mathrm{CC},-5 \mathrm{H}-\mathrm{CC}$, and $-9 \mathrm{H}-\mathrm{CC}$. Moderately diverse, well-preserved faunas are present and indicate a Quaternary age. The faunas present typically include Didymocyrtis tetrathalamus, Lamprocyclas maritalis, Botryostrobus auritus/australis group, Amphirhopalum ypsilon, and Spongaster tetras. The occurrence of Druppatractus acquilonius in Sample 126-792A-5H-CC and Axoprunum angelinum in Sample 126-792A-9H-CC provides minimum age constraints of 0.3 and $0.41 \mathrm{Ma}$ for samples at and below these levels (Foreman, 1981).

Moderately diverse, well-preserved radiolarian faunas are present in core-catcher samples from all cores of Hole 792B except for Samples 126-792B4X-CC, -8X-CC, and -10X-CC. The occurrence of faunas including Tetrapyle octacantha, Didymocyrtis tetrathalamus, and Spongaster tetras suggest a late Pliocene to Holocene age. Upper Pliocene to Holocene radiolarians are common and well preserved in Sample 126-792C-1X-CC from Hole 792C. In Hole 792D, Sample 126-792D-1X-CC contains abundant, well-preserved radiolarians. The co-occurrence of Spongaster tetras and Spongaster pentas in this sample suggests assignment to the upper part of the upper Pliocene Spongaster pentas Zone of Sanfilippo et al. (1985).

Well-preserved lower Miocene to upper Pliocene radiolarians are common in the upper half of Hole 792E. All samples from below the level of Sample 126-792E-28R-2, 20-21 cm, are devoid of identifiable radiolarians. However, extremely poorly preserved, infilled radiolarians occur in Sample 126-792E-30R-CC and were also observed sporadically below this sample. Samples 126-792E-1R-1, 2-3 cm, through $-5 \mathrm{R}-1,19-20 \mathrm{~cm}$, contain an assemblage that includes Druppatractus acquilonius, Amphirhopalum ypsilon, Spongaster tetras, S. pentas, Pterocanium prismatium, and Stichocorys peregrina. The presence of Amphirhopalum ypsilon in these samples indicates an age $<3.78 \mathrm{Ma}$ (Backman et al., 1988) and that of Spongaster tetras an age of $<3.8 \mathrm{Ma}$ (Backman et al., 1988). The occurrence of Spongaster pentas together with Didymocyrtis avita in Sample 126-792E-2R-1, 5-6 cm, suggests assignment to the Spongaster pentas Zone of Pliocene age (Sanfilippo et al., 1985). No diagnostic radiolarians were recovered between Sample 126-792E5R-1, 19-20 cm, and Sample 126-792E-9R-1, 21-22 cm. Sample 
Table 1. Radiolarians at Hole 787B.

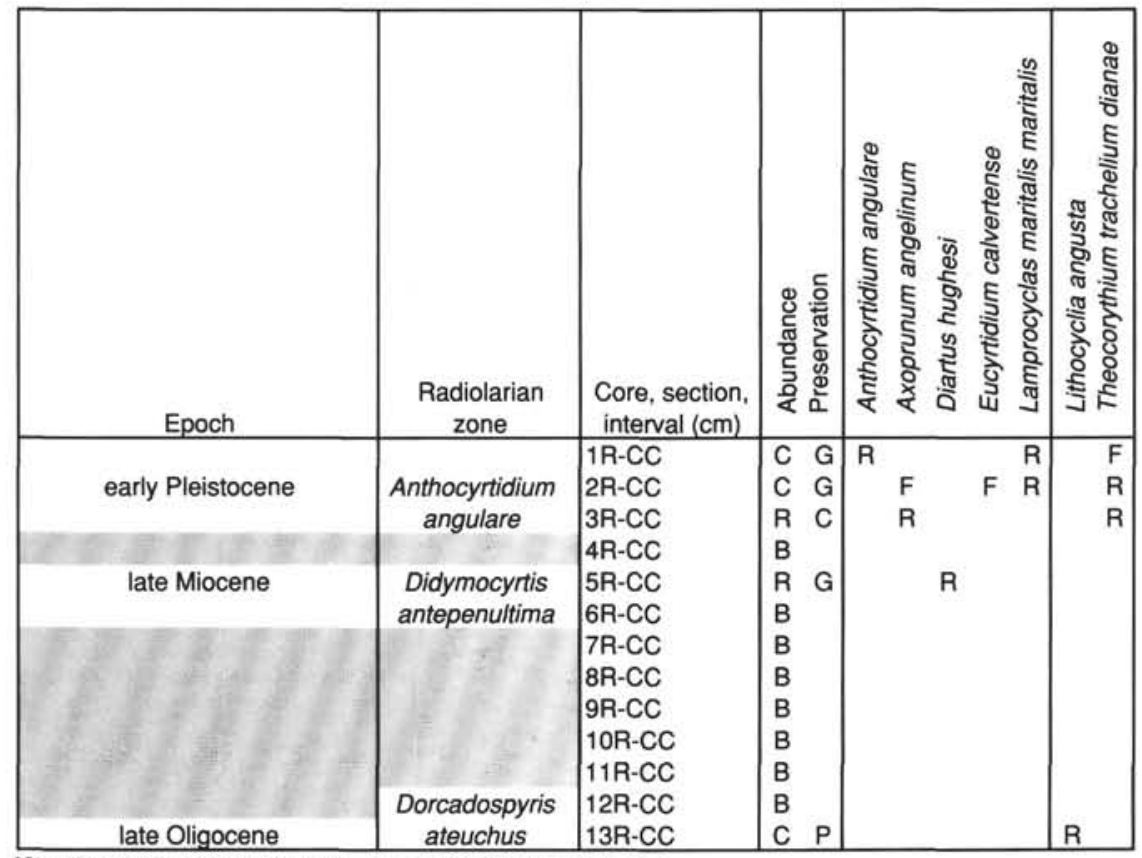

Note: Shaded area represents zone barren of identifiable radiolarians.

Table 2. Radiolarians at Hole 790A.

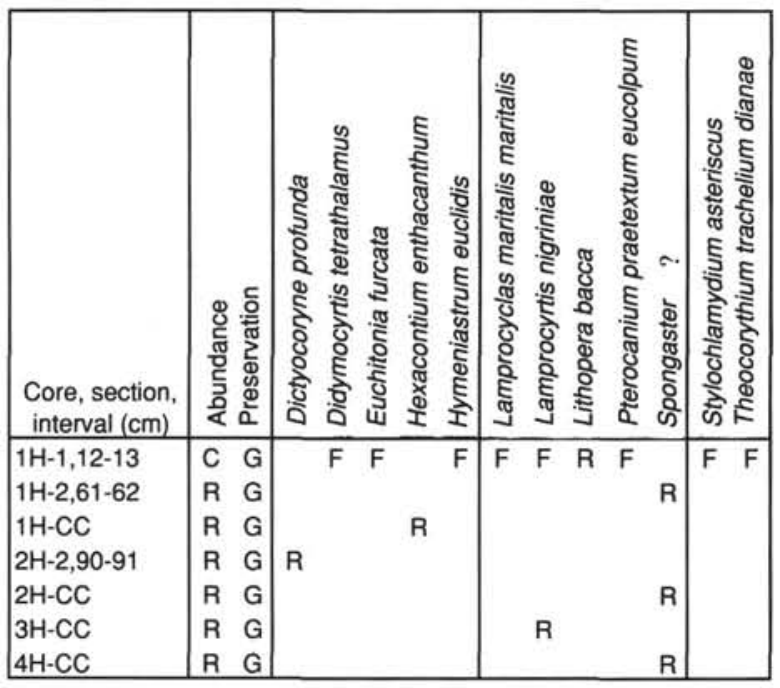

126-792E-9R-1, 21-22 cm, contains Stichocorys delmontensis and is therefore no younger than upper Miocene (6.4 Ma; Backman et al., 1988). This sample was tentatively assigned to the Didymocyrtis penultima Zone of Sanfilippo et al. (1985). Samples 126-792E-15R$\mathrm{CC}$ through $-22 \mathrm{R}-\mathrm{CC}$ contain an upper middle Miocene fauna that includes Stichocorys delmontensis, Cyrtocapsella japonica, and Didymocyrtis laticonus. The presence of Didymocyrtis laticonus suggests assignment to the upper middle Miocene Diartus petterssoni Zone of Sanfilippo et al. (1985).

Stichocorys wolffii occurs in and below Sample 126-792E-18RCC. The last occurrence (LO) of this species is in the latest middle Miocene at 11.6 Ma (Nigrini, 1985). Both Stichocorys wolffii and Cyrtocapsella japonica occur in Sample 126-792E-23R-CC. Didymocyrtis laticonus, which is common at levels above this sample, is
Table 3. Radiolarians at Hole 790B.

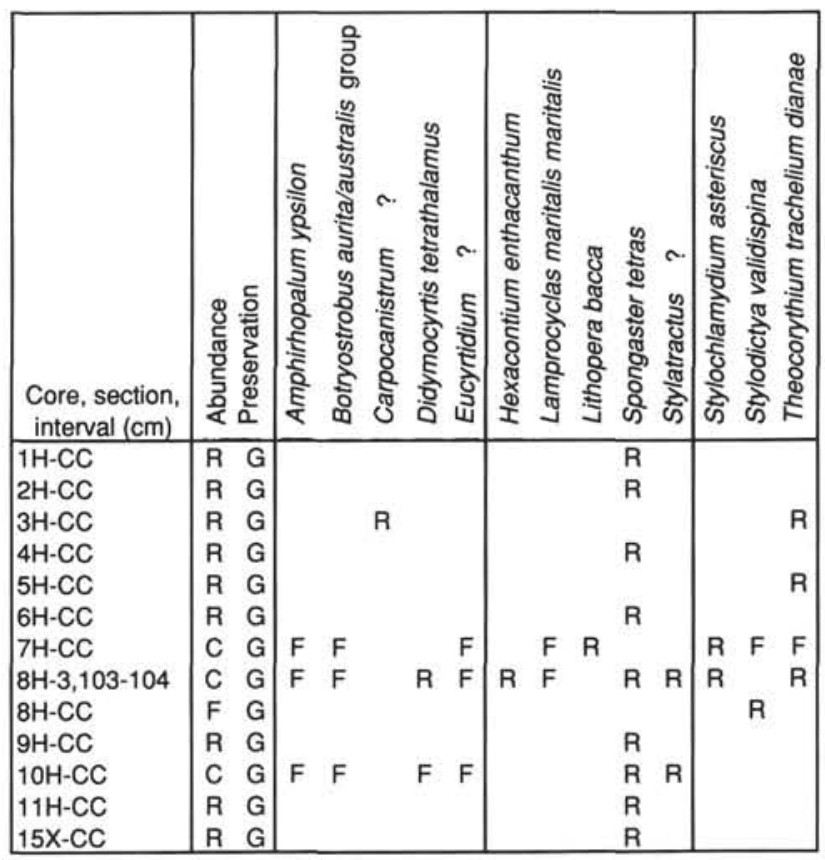

absent, which suggests assignment to the lower middle Miocene Dorcadospyris alata Zone of Sanfilippo et al. (1985).

Samples 126-792E-24R-CC through -27R-CC are barren of radiolarians. Sample 126-792E-28R-2, 20-21 cm, contains one identifiable species, Cyrtocapsella japonica, which allows the assignment of a Miocene age. This species is known to occur in the Cyrtocapsella tetrapera through Diartus petterssoni zones (Nigrini and Lombari, 1984). No identifiable radiolarians were recovered from below Sample 126-792E-28R-2, 20-21 cm. 


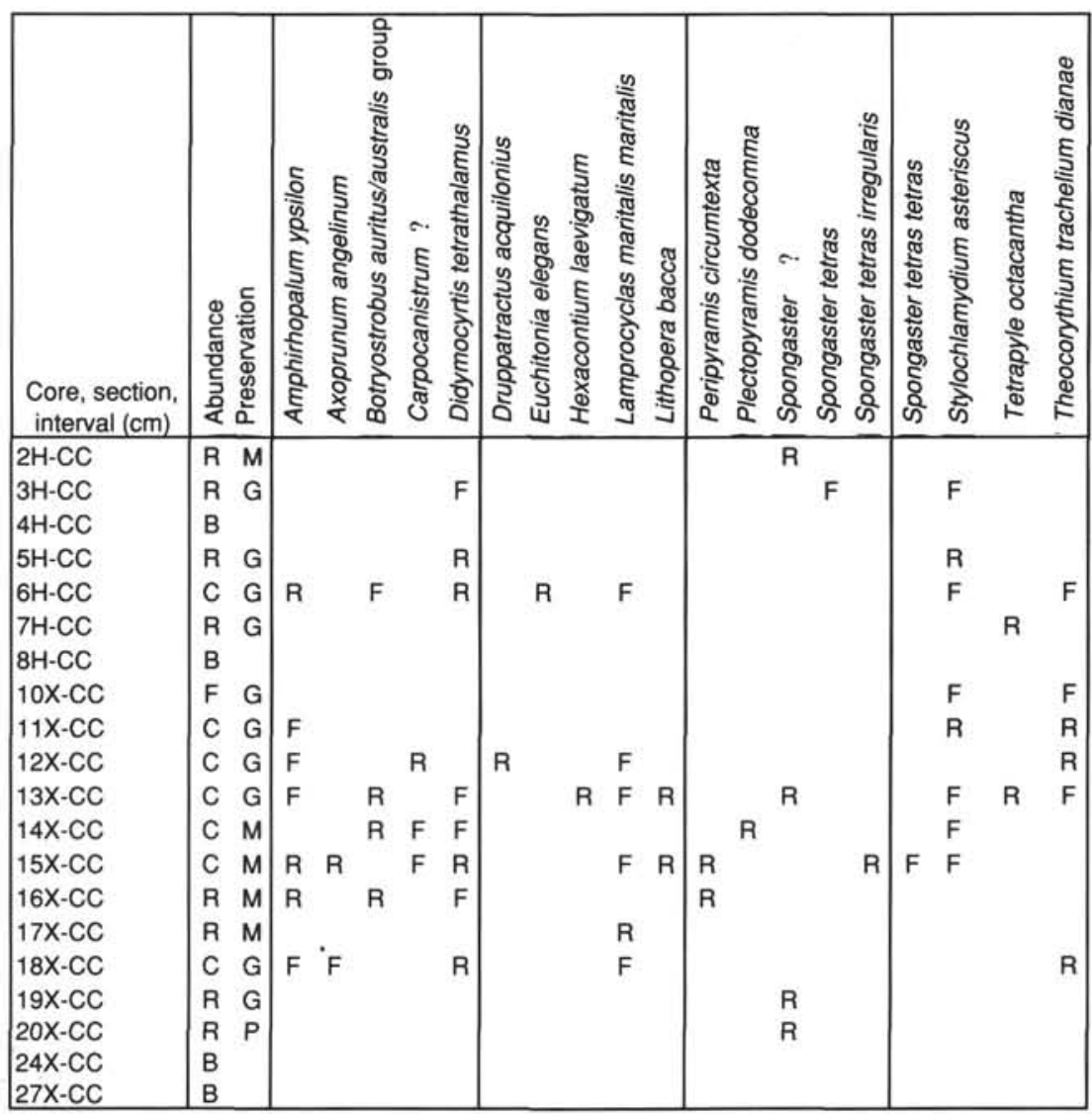

\section{Site 793}

All core-catcher samples from Hole 793A were examined. Quaternary radiolarians are present in all samples except Samples 126793A-2H-CC and -8H-CC (Tables 12 and 13). The occurrence of Druppatractus aquilonius in and below Sample 126-793A-3H, $0 \mathrm{~cm}$, indicates an age of $>300$ k.y. for samples at and below this level (Foreman, 1981).

Rare, moderately preserved radiolarians are present in samples from Hole 793B in Sample 126-793B-2R-CC and Samples 126793B-4R-CC through -8R-CC. The presence of Cyrtocapsella tetrapera and Stichocorys wolffii in these samples suggests assignment to the upper lower to lower middle Miocene Calocycletta costata or Didymocyrtis alata zones. No identifiable faunas were found in, or below, Sample 126-793B-9R-CC. Radiolarians are present in many samples but are typically infilled and have suffered considerable dissolution.

\section{CONCLUSION}

Radiolarians were recovered from Miocene to Quaternary sections drilled on Leg 126. They provide important data that will help fill an informational gap in the radiolarian distribution at mid-latitudes in the western Pacific. Radiolarian preservation is discontinuous; and, although present in abundance in some Oligocene sections, specimens are poorly preserved. This is probably a result of partial dissolution of radiolarian tests during diagenesis.

\section{SPECIES LIST}

Detailed original descriptions of the radiolarian species identified in samples from various Leg 126 sites have already been presented. Therefore, the following list simply provides a bibliographic reference for the species in this paper. In most cases, only the reference containing the original description is presented, except where this description differs from present consensus or has been revised. The species are listed in alphabetical order.

Amphirhopalum ypsilon Haeckel

Amphirhopalum ypsilon Haeckel, 1887, p. 522; Nigrini, 1967, p. 35, pl. 3, $3 a-3 d$

Androcyclas gamphonycha (Jørgensen)

Pterocorys gamphonyxos Jørgensen, 1899, p. 86

P. theoconus Jørgensen, $P$. ambycephalis Jørgensen 1899, p. 86

Androcyclas gamphonycha (Jørgensen, 1905, p. 139, pl. XVIII, figs. 92-97; Hays, 1965, p. 178, pl. III, fig. 2

Anomalacantha dentata (Mast)

Heteracantha dentata Mast, 1910, p. 157; Nigrini, 1970, p. 167, pl. 1, fig. 9 Cladococcus lychnosphaera Hollande and Enjumet, 1960, p. 115, pl. 55, figs. 1-2

Anomalacantha dentata (Mast), in Benson, 1966, p. 170, pl. 5, figs. 10-11

Anthocyrtidium angulare Nigrini

Anthocyrtidium angulare Nigrini, 1971, p. 445, pl. 34.1, figs. 3a-3b 
Table 5. Radiolarians at Hole 791A.

\begin{tabular}{|c|c|c|c|c|c|c|c|c|}
\hline $\begin{array}{c}\text { Core, section, } \\
\text { interval }(\mathrm{cm})\end{array}$ & 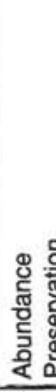 & & 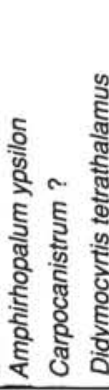 & 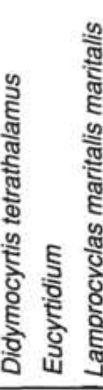 & 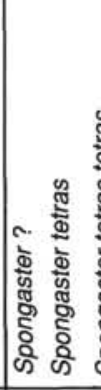 & 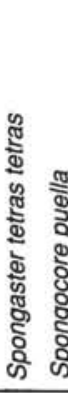 & 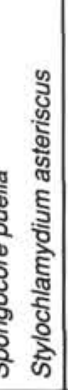 & 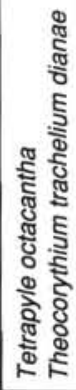 \\
\hline $2 \mathrm{H}-\mathrm{CC}$ & & & & & R & & $\mathrm{R}$ & $R$ \\
\hline $3 \mathrm{H}-\mathrm{CC}$ & R 1 & & & & $R$ & & & \\
\hline $4 \mathrm{H}-\mathrm{CC}$ & & & & & & $R$ & $\mathrm{~F}$ & \\
\hline $5 \mathrm{H}-\mathrm{CC}$ & & & & & R & & & \\
\hline $6 \mathrm{H}-\mathrm{CC}$ & & & & & R & & & \\
\hline $7 \mathrm{H}-\mathrm{CC}$ & & M & & $\mathrm{F}$ & & & & R \\
\hline $8 \mathrm{H}-\mathrm{CC}$ & B & & & & & & & \\
\hline $9 \mathrm{H}-\mathrm{CC}$ & B & & & & & & & \\
\hline $10 \mathrm{H}-\mathrm{CC}$ & B & & & & & & & \\
\hline $11 \mathrm{H}-\mathrm{CC}$ & B & & & & & & & \\
\hline $12 \mathrm{H}-\mathrm{CC}$ & $R$ & $P$ & & & R & & & \\
\hline $14 \mathrm{H}-\mathrm{CC}$ & B & & & & & & & \\
\hline $15 \mathrm{H}-\mathrm{CC}$ & & $P$ & & & R & & $F$ & $B$ \\
\hline $16 \mathrm{H}-\mathrm{CC}$ & & $P$ & & $R \quad F$ & & & & $R$ \\
\hline $17 \mathrm{H}-\mathrm{CC}$ & & $P$ & & & $R$ & & & \\
\hline $18 \mathrm{H}-\mathrm{CC}$ & B & & & & & & & \\
\hline $\mid \begin{array}{l}19 \mathrm{H}-\mathrm{CC} \\
20 \mathrm{H}-\mathrm{CC}\end{array}$ & & $\mathrm{P}$ & & & R & & & \\
\hline 21R-CC & & $P$ & & & $R$ & & & \\
\hline 22R-CC & & $\mathrm{M}$ & & & & R & & \\
\hline $23 \mathrm{H}-\mathrm{CC}$ & B & & & & & & & \\
\hline $25 \mathrm{X}-\mathrm{CC}$ & B & & & & & & & \\
\hline $28 \mathrm{X}-\mathrm{CC}$ & B & & & & & & & \\
\hline $30 \mathrm{x}-\mathrm{CC}$ & B & & & & & & & \\
\hline $31 \mathrm{X}-\mathrm{CC}$ & $\mathrm{F}$ & $M$ & $R$ & R & & 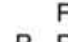 & $\begin{array}{ll}R & F \\
& \end{array}$ & \\
\hline $32 \mathrm{X}-\mathrm{CC}$ & C & $\mathrm{M}$ & $\mathrm{R}$ & R & & $\mathrm{R} P$ & $\begin{array}{ll}\mathrm{R} & \mathrm{R} \\
\end{array}$ & \\
\hline $\begin{array}{l}33 X-C C \\
34 X-C C\end{array}$ & $\begin{array}{l}\text { B } \\
\text { B }\end{array}$ & & & & & & & \\
\hline $35 \mathrm{X}-\mathrm{CC}$ & & M & & R & & & $\mathrm{R}$ & \\
\hline $38 \mathrm{X}-\mathrm{CC}$ & C & M & $R \quad R \quad R$ & $R \quad R$ & & & $\mathrm{R}$ & $\mathrm{R}$ \\
\hline $39 X-C C$ & B & & & & & & & \\
\hline $40 \mathrm{X}-\mathrm{CC}$ & & $\mathrm{P}$ & & & R & & & \\
\hline $41 X-C C$ & R & $\mathrm{M}$ & & & R & & & \\
\hline $42 X-C C$ & B & & & & & & & \\
\hline $46 \mathrm{X}-\mathrm{CC}$ & R & $\mathrm{P}$ & & & $\mathrm{R}$ & & & \\
\hline
\end{tabular}

Anthocyrtidium ophirense (Ehrenberg)

Anthocyrtis ophirensis Ehrenberg, 1872, p. 301; Haeckel, 1887, p. 1270

Anthocyrtidium ophirense (Ehrenberg), in Nigrini, 1967, p. 56, pl. 6, fig. 3

Anthocyrtidium zanguebaricum (Ehrenberg)

Anthocyrtis zanguebarica Ehrenberg, 1872, p. 301

Anthocyrtidium zanguebaricum (Ehrenberg), in Nigrini, 1967, p. 58, pl. 6, fig. 4

Axoprunum angelinum (Campbell and Clark)

Stylosphaera angelina Campbell and Clark, 1944, p. 12, pl. 1, figs. 14-20

Axoprunum angelinum (Campbell and Clark), in Kling, 1973, p. 634

Botryostrobus auritus/australis (Ehrenberg) group

Lithocampe aurita Ehrenberg, 1844a, p. 84

Lithocampe australe Ehrenberg, 1844b, p. 187

Lithostrobus seriatus Haeckel, 1887, p. 1474, pl. 79, fig. 15; Petrushevskaya,

1967 , p. 145 , pl. 82 , figs. I-IV; 1971 , pl. 24 , figs. 6-8

Botryostrobus auritus/australis (Ehrenberg) group Nigrini, 1977, p. 246, pl. 1, figs. 2-5
Carpocanopsis bramlettei Riedel and Sanfilippo

Cycladophora favosa Haeckel, in Riedel, 1954, pl. 1, fig. 3

Carpocanopsis bramlettei Riedel and Sanfilippo, 1971, p. 1597, pl. 2G, figs. $8-14$; pl. 8, fig. 7

Carpocanopsis favosa (Haeckel)

Cycladophora favosa Haeckel, 1887, p. 1380, pl. 62, figs. 5-6

Carpocanopsis favosum (Haeckel), in Riedel and Sanfilippo, 1971, p. 1597, pl. 2G, figs. 15-16; pl. 8, figs. 9-10

Carpocanopsis favosa (Haeckel), in Sanfilippo and Riedel, 1973, p. 531

Cenosphaera cristata Haeckel

Cenosphaera cristata Haeckel 1887, p. 66, in Riedel, 1958, p. 223, pl. 1, figs. 1-2

Cenosphaera cristata Haeckel?, in Nigrini and Moore, 1979, p. S41, pl.

$$
4 \text {, figs. } 2 a-2 b
$$

Cornutella profunda Ehrenberg

Cornutella clathrata B profunda Ehrenberg, 1854, p. 241

Cornutella profunda Ehrenberg, Riedel, 1958, p. 232, pl. 3, figs. 1-2

Cornutella profunda Ehrenberg, in Nigrini, 1967, p. 60, pl. 6, figs. 5a-5c

Cyrtocapsella japonica (Nakaseko)

Eusyringium japonicum Nakaseko, 1963, p. 193, pl. 4, figs. 1-3

Cyrtocapsella japonica (Nakaseko), in Sanfilippo and Riedel, 1970, p. 452, pl. 1, figs. 13-15

Cyrtocapsella tetrapera (Haeckel)

Cyrtocapsa tetrapera Haeckel, 1887, p. 1512, pl. 78, fig. 5

Cyrtocapsella tetrapera (Haeckel), in Sanfilippo and Riedel, 1970, p. 453, pl. 1, figs. 16-18

Diartus hughesi (Campbell and Clark)

Ommatocampe hughesi Campbell and Clark, 1944, p. 23, pl. 3, fig. 12

Diartus hughesi (Campbell and Clark), in Sanfilippo and Riedel, 1980, p. 1010

Dictyocoryne profunda Ehrenberg

Dictyocoryne profunda Ehrenberg, 1860a, p. 767

Dictyocoryne truncatum (Ehrenberg)

Rhopalodictyum truncatum Ehrenberg, 1860b, p. 301; Haeckel, 1887, p. 589

Dictyocoryne cf. truncatum (Ehrenberg), in Benson, 1966, p. 235, pl. 15, fig. 1

Dictyophimus hirundo (Haeckel) group

Pterocorys hirundo Haeckel, 1887, p. 1318, pl. 71, fig. 4; Riedel, 1958, p. 238, pl. 3, fig. 11; pl. 4, fig. 1; text-fig. 9

Didymocyrtis avita (Riedel)

Panartus avitus Riedel, 1953 , p. 808 , pl. 84 , fig. 7

Ommatartus avitus (Riedel), in Riedel and Sanfilippo, 1971, p. 1588

Didymocyrtis avita (Riedel), in Sanfilippo and Riedel, 1980, p. 1010

Didymocyrtis laticonus (Riedel)

Cannartus laticonus Riedel, 1959, pl. 291, pl. 1, fig. 5

Didymocyrtis laticonus (Riedel), in Sanfilippo and Riedel, 1980, p. 1010

Didymocyrtis tetrathalamus (Haeckel)

Panartus tetrathalamus Haeckel, 1887, p. 378, pl. 40, fig. 3

Ommatartus tetrathalamus (Haeckel), in Riedel and Sanfilippo, 1971, p. 1588

Didymocyrtis tetrathalamus (Haeckel), in Sanfilippo and Riedel, 1980, p. 1010

Druppatractus acquilonius Hays

Druppatractus acquilonius Hays, 1970, p. 214, pl. 1, figs. 4 and 5

Stylacontarium acquilonium (Hays), in Kling, 1973, p. 634; Ling, 1973, p. 777 , pl. 1 , figs. 6 and 7

Euchitonia elegans (Ehrenberg)

Pteractis elegans Ehrenberg, 1872, p. 319

Euchitonia elegans (Ehrenberg), in Nigrini, 1967, p. 39, pl. 4, figs. 2a-2b

Euchitonia furcata Ehrenberg

Euchitonia furcata Ehrenberg, 1872, p. 308

Eucyrtidium acuminatum (Ehrenberg)

Lithocampe acuminatum Ehrenberg, 1844a, p. 84

Eucyrtidium acuminatum (Ehrenberg), Nigrini, 1967, p. 81, pl. 8, figs. 3a-3b

Eucyrtidium calvertense Martin

Eucyrtidium calvertense Martin, in Kling, 1973, pl. 4, figs. 16 and 18-19; pl. 11, figs. $1-5$

Eucyrtidium hexagonatum Haeckel

Eucyrtidium hexagonatum Haeckel, 1887, p. 1489, pl. 80, fig. 11 


\section{J. C. AITCHISON}

Table 6. Radiolarians at Hole 791B.

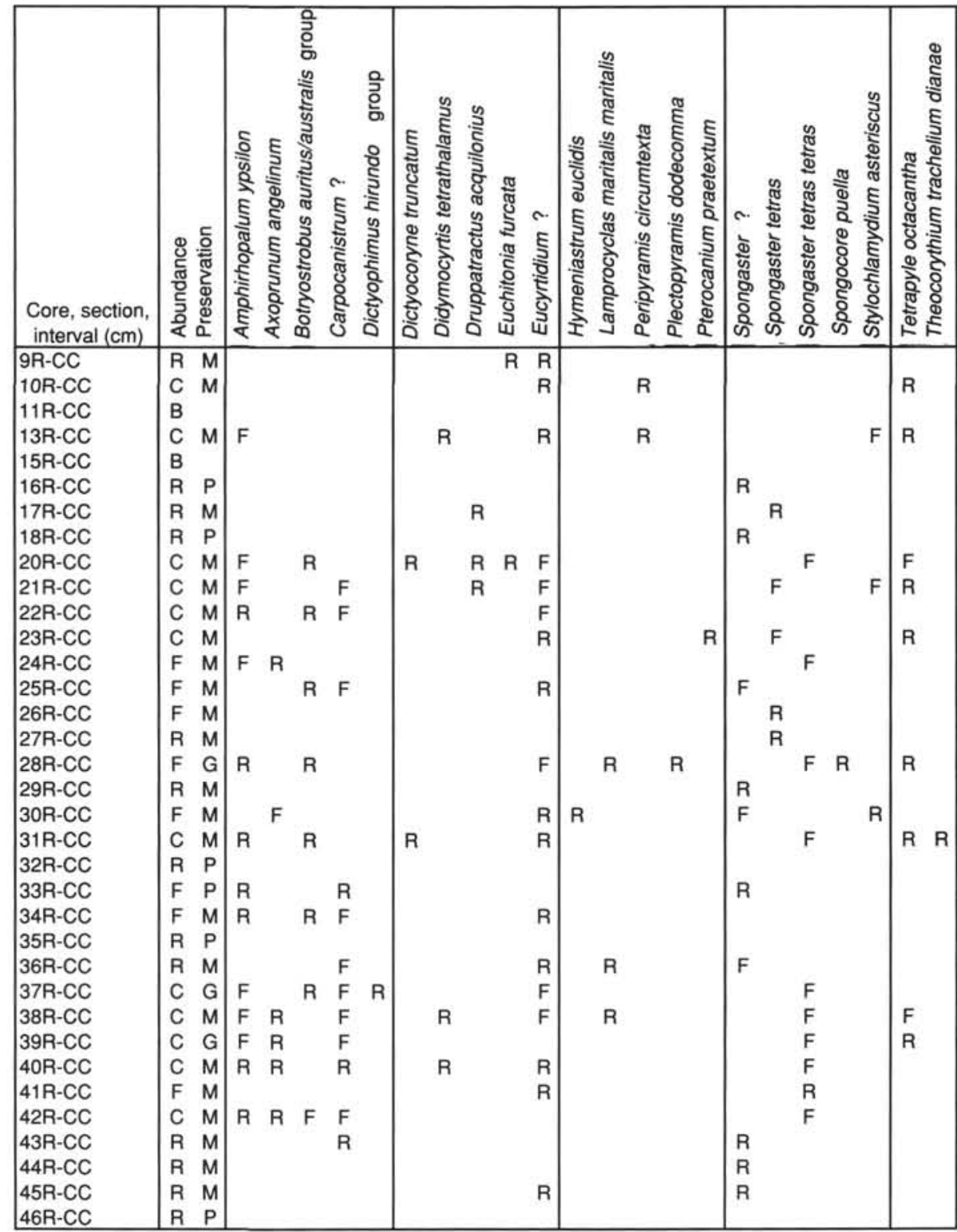

Heliodiscus asteriscus Haeckel

Heliodiscus asteriscus Haeckel, 1887, p. 445, pl. 33, fig. 8

Hexacontium enthacanthum Jørgensen

Hexacontium enthacanthus Jørgensen, 1899, p. 52, pl. 2, fig. 14; pl. 4, fig. 20

Hexacontium enthacanthum Jørgensen, in Benson, 1966, p. 149, pl. 3, figs. $13-14$; pl. 4 , figs. $1-3$

Hexacontium laevigatum Haeckel

Hexacontium laevigatum Haeckel, 1887 p. 193, pl. 24, fig. 6

Hymeniastrum euclidis Haeckel

Hymeniastrum euclidis Haeckel, 1887, p. 531, pl. 43, fig. 13

Lamprocyclas maritalis maritalis Haeckel

Lamprocyclas maritalis Haeckel, 1887, p. 1390, pl. 74, figs. 13-14

Lamprocyclas maritalis maritalis Haeckel, in Nigrini, 1967, p. 74-76, pl. 7 , fig. 5

Lamprocyrtis hannai (Campbell and Clark)

Calocyclas hannai Campbell and Clark, 1944, p. 48, pl. 6, figs. 21-22 Lamprocyrtis (?) hannai (Campbell and Clark), in Kling, 1973, p. 638, pl. 5 , figs. $12-14$; pl. 12 , figs. $10-14$

Lamprocyrtis heteroporos (Hays)

Lamprocyclas heteroporus Hays, 1965, p. 179, pl. 3, fig. 1

Lamprocyrtis heteroporos (Hays), in Kling, 1973, p. 639, pl. 5, figs. 19-21; pl. 15 , fig. 6

Lamprocyrtis nigriniae (Caulet)

Conarachnium nigriniae Caulet, 1971, p. 3, pl. 3, figs. 1-4; pl. 4, figs. 1-4 Lamprocyrtis nigriniae (Caulet), in Kling, 1977, p. 217.

Liriospyris mutuaria Goll

Liriospyris mutuaria Goll, 1968, p. 1428, pl. 175, figs. 6, 10, 11, and 14; text-fig. 9 
Table 7. Radiolarians at Hole 792A.

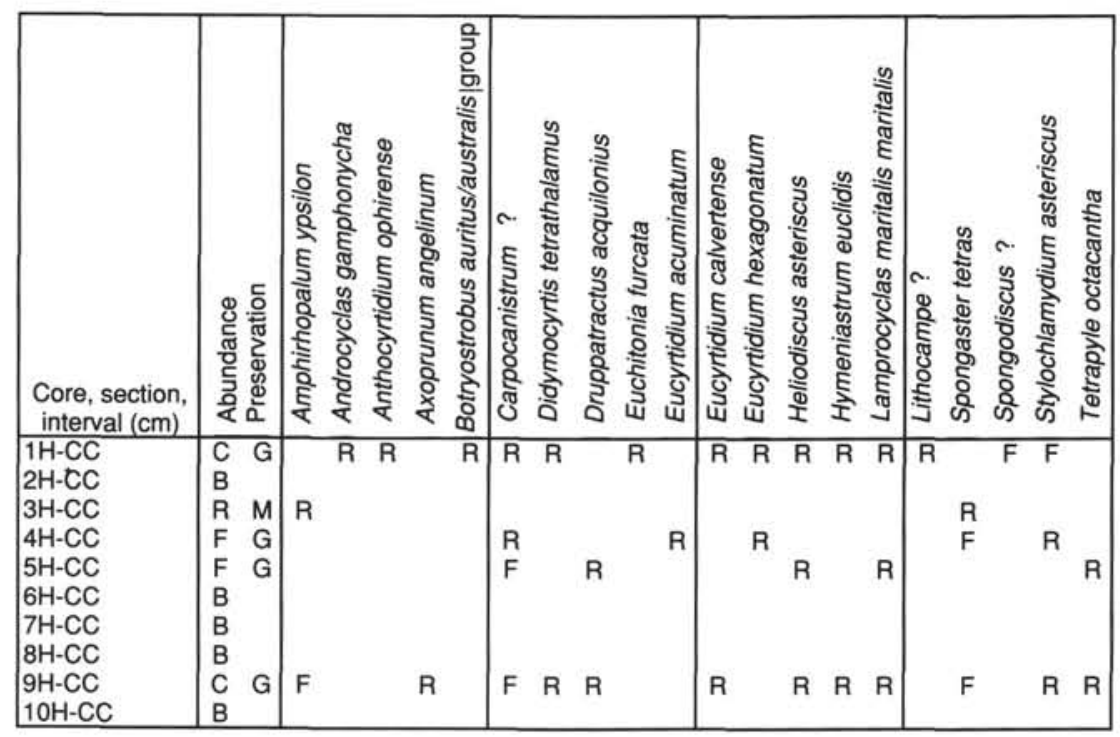

Table 8. Radiolarians at Hole 792B.

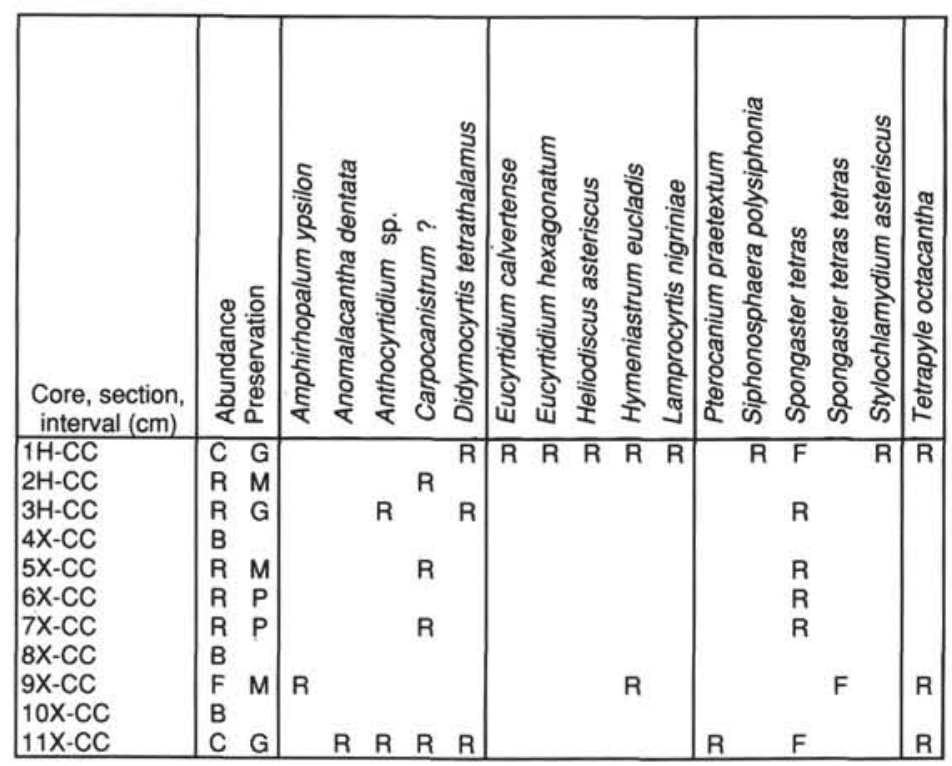

Table 9. Radiolarians at Hole 792C.

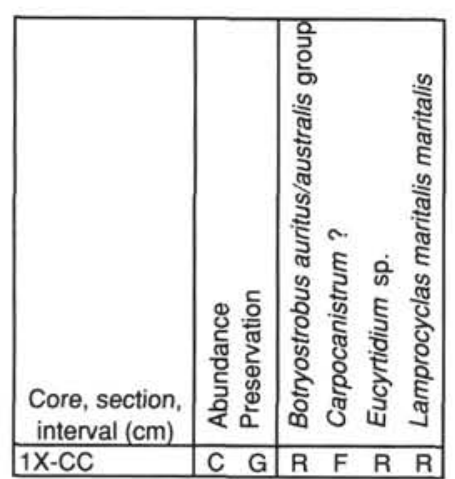

Liriospyris stauropora (Haeckel)

Trissocyclus stauroporus Haeckel, 1887, p. 987, pl. 83, fig. 5

Liriospyris stauropora (Haeckel), in Goll, 1968, p. 1431, pl. 175, figs. 1-3; text-fig. 9

Lithelius nautiloides Popofsky

Lithelius nautiloides Popofsky, 1908, p. 230, pl. 27, fig. 4

Lithocyclia angusta (Riedel)

Trigonactura angusta Riedel, 1959, p. 292, pl. 1, fig. 6

Lithocyclia angustum (Riedel), in Riedel and Sanfilippo, 1970, p. 522, pl. 13 , figs. $1-2$

Lithopera bacca Ehrenberg

Lithopera bacca Ehrenberg, 1872, p. 314; Sanfilippo and Riedel, 1970, p. 455

Peripyramis circumtexta Haeckel

Peripyramis circumtexta Haeckel, 1887, p. 1162, pl. 54, fig. 5 


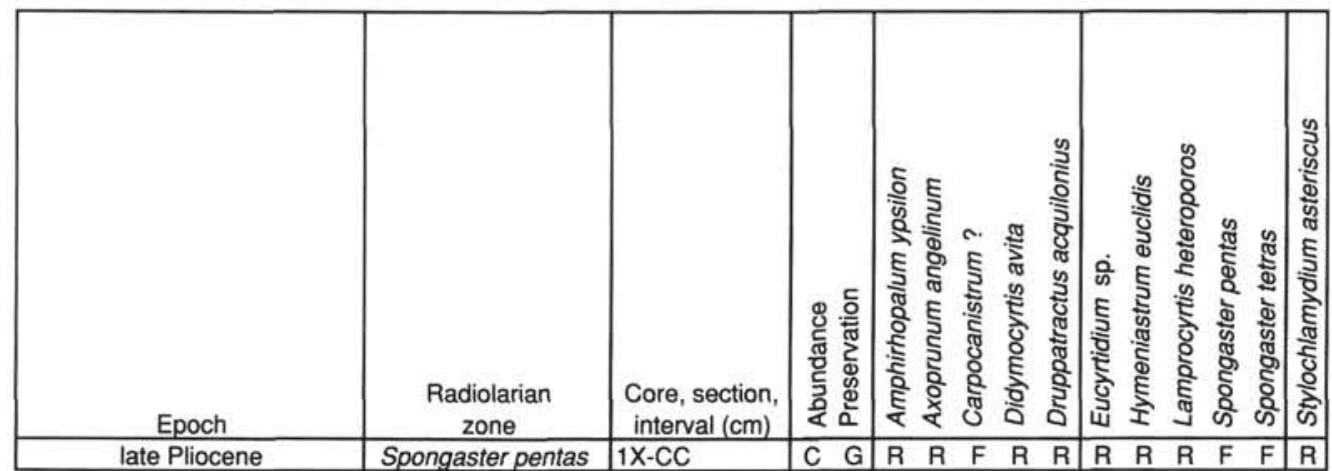

Phormostichoartus doliolum (Riedel and Sanfilippo)

Artostrobium doliolum Riedel and Sanfilippo, 1971, p. 1599, pl. 1H, figs. $1-3$; pl. 8, figs. 14-15

Phormostichoartus doliolum (Riedel and Sanfilippo), in Nigrini, 1977, p. 252 , pl. 1 , fig. 14

Plectopyramis dodecomma Haeckel

Plectopyramis dodecomma Haeckel, 1887, p. 1258, pl. 54, fig. 6

Pterocanium prismatium Riedel Pterocanium prismatium Riedel, 1957, p. 87, pl. 3, figs. 4-5 emend. Riedel and Sanfilippo, 1970, p. 529

Pterocanium praetextum (Ehrenberg) eucolpum Haeckel Pterocanium eucolpum Haeckel, 1887, p. 1322, pl. 73, fig. 4

Pterocanium praetextum (Ehrenberg) eucolpum Haeckel, in Nigrini, 1967, p. 70 , pl. 7 , fig. 2

Pterocanium trilobum (Haeckel)

Dictyopodium trilobum Haeckel, 1860, p. 839

Pterocanium trilobum (Haeckel), in Nigrini, 1967, p. 71, pl. 7, figs. 3a-3b

Siphonosphaera polysiphonia Haeckel

Siphonosphaera polysiphonia Haeckel, 1887, p. 106

Spongaster pentas Riedel and Sanfilippo

Spongaster pentas Riedel and Sanfilippo, 1970, p. 523, pl. 15, fig. 3

Spongaster tetras Ehrenberg

Spongaster tetras Ehrenberg, 1860b, p. 833

Spongaster tetras Ehrenberg irregularis Nigrini

Spongaster tetras Ehrenberg irregularis Nigrini, 1967, p. 43, pl. 5, fig. 2

Spongaster tetras tetras Ehrenberg

Spongaster tetras tetras Ehrenberg, in Nigrini, 1967, p. 41-43, pl. 5, figs. 1a-1b

Spongocore puella Haeckel

Spongocore puella Haeckel, 1887, p. 347, pl. 48, fig. 6

Stichocorys delmontensis (Campbell and Clark)

Eucyrtidium delmontense Campbell and Clark, 1944, p. 56, pl. 7, figs. 19-20 Stichocorys delmontensis (Campbell and Clark), in Sanfilippo and Riedel, 1970, p. 451, pl. 1, fig. 9

Stichocorys peregrina (Riedel)

Eucyrtidium elongatum peregrinum Riedel, 1953, p. 812, pl. 85, fig. 2

Stichocorys peregrina (Riedel), in Sanfilippo and Riedel, 1970, p. 451, pl. 1 , fig. 10

Stichocorys wolffii Haeckel

Stichocorys wolffii Haeckel, 1887, p. 1479.

Stylochlamydium asteriscus Haeckel

Stylochlamydium asteriscus Haeckel, 1887, p. 514, pl. 41, fig. 10
Stylodictya validispina Jørgensen

Stylodictya validispina Jørgensen, 1905, p. 119, pl. 10, fig. 40

Tetrapyle octacantha Miiller

Tetrapyle octacantha Müller, 1858, p. 33, pl. 2, figs. 12 and 13; pl. 3, figs. 1-12

Theocorythium trachelium (Ehrenberg) dianae (Haeckel)

Theocorys dianae Haeckel, 1887, p. 1416, pl. 69, fig. 11

Theocorythium trachelium (Ehrenberg) dianae (Haeckel), in Nigrini, 1967 , p. 77 , pl. 8, figs. 1a-1b; pl. 9, figs. 1a-1b

\section{REFERENCES}

Backman, J., Duncan, R. A., et al., 1988. Proc. ODP, Init. Repts., 115: College Station, TX (Ocean Drilling Program).

Barron, J. A., Nigrini, C. A., Pujos, A., Saito, T., Theyer, F., Thomas, E., and Weinreich, N., 1985b. Synthesis of biostratigraphy, central equatorial Pacific, Deep Sea Drilling Project Leg 85: refinement of Oligocene to Quaternary biochronology. In Mayer, L., Theyer, F., Thomas, E., et al., Init. Repts. DSDP, 85: Washington (U.S. Govt. Printing Office), 905-934.

Benson, R. N., 1966. Recent Radiolaria from the Gulf of California [Ph.D. dissert.]. Minnesota Univ.

Campbell, A. S., and Clark, B. L., 1944. Miocene radiolarian faunas from Southern California. Spec. Pap. Geol. Soc. Am., 51:1-76.

Caulet, J., 1971. Contribution a l'étude de quelques Radiolaries Nassellaires des boues de la Méditerranée et du Pacifique. Archives originale, Centre de Documentation, C.N.R.S., No. 498. Cah. Micropaleontol., Ser. 2, 10:1-10.

Ehrenberg, C. G., 1844a. Einige vorläufige Resultate seiner Untersuchungen der ihm von der Südpolreise des Capitain Ross, so wie von der Herren Schayer und Darwin zugekommenen Materialien über das Verhalten des kleinsten Lebens in den Oceanen und den grossten bisher zuganglichen Tiefen des Weltmeers vor. Abh. K. Preuss. Akad. Wiss. Berlin, 182-207. 1844b. Über 2 neue Lager von Gebirgsmassen aus Infusorien als Meeres-Absatz in Nord-Amerika und eine Vergleichung derselben mit den organischen Kreide-Gebilden in Europa und Afrika. K. Preuss. Akad. Wiss. Berlin, Bericht, 57-97.

1854. Die systematiche Charakteristik der neuen mikroskopischen Organismen des tiefen Atlantischen Oceans. Monatsber. K. Preuss. Akad. Wiss. Berlin, Bericht, Jahrg. 1854:236-250.

, $1860 \mathrm{a}$. Über den Tiefgrund des stillen Oceans zwischen Californien und den Sandwich-Inseln aus bis 15600' Tiefe nach Lieutenant Brooke. Monatsber. K. Preuss. Akad. Wiss. Berlin, 819-833.

1860b. Über die organischen und unorganischen Mischungsverhaltnisse des Meeresgrundes in 19,800 Fuss Tiefe nach Lieut. Brookes Messung. Monatsber. K. Preuss. Akad. Wiss. Berlin, Jahrg. 1860:765-774. 1872. Mikrogeologische Studien als Zusammenfassung der Beobachtungen des kleinsten Lebens der Meeres-Tiefgrunde aller Zonen und dessen geologischen Einfluss. Monatsber. K. Preuss. Akad. Wiss. Berlin, 265-322.

Foreman, H. P., 1981. Radiolaria. In Emiliani, C. (Ed.), The Sea (Vol. 6): New York (Wiley), 1121-1144.

Goll, R. M., 1968. Classification and phylogeny of Cenozoic Trissocyclidae (Radiolaria) in the Pacific and Caribbean basins. Part I. J. Paleontol., 42:1409-1432. 
Table 11. Radiolarians at Hole 792E.

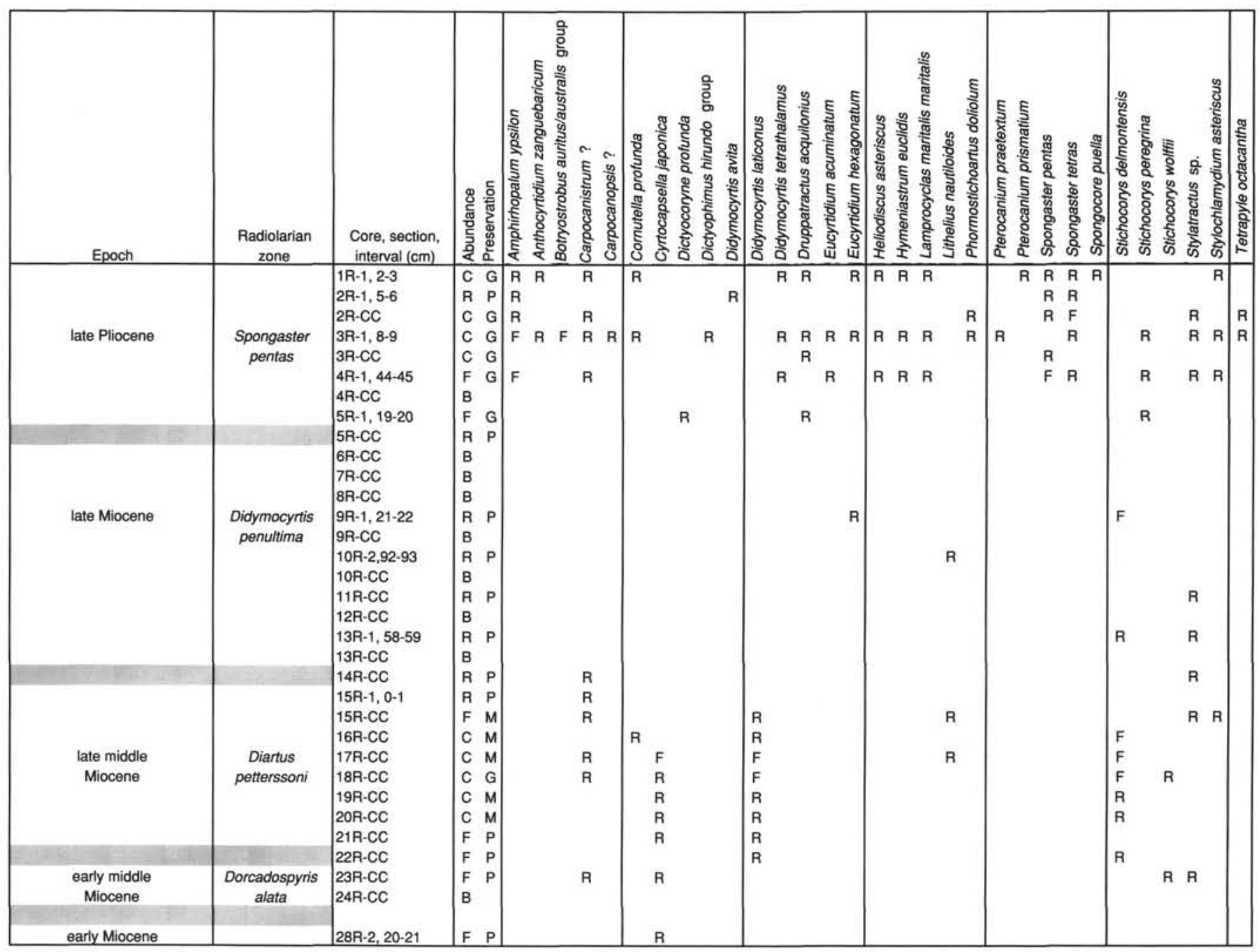

Haeckel, E., 1860. Fernere Abbildungen und Diagnosen neuer Gattungen und Arten von lebenden Radiolarien des Mittelmeeres (Supplementary illustrations and diagnosis of new genera and species of living radiolarians of the Mediterranean Sea). Monatsber. K. Preuss. Akad. Wiss. Berlin, 835-845.

, 1887. Report on the Radiolaria collected by H.M.S. Challenger during the years 1873-1876. Rep. Sci. Results Voy. H.M.S. Challenger, Zool., 18:1-1303.

Hays, J. D., 1965. Radiolaria and late Tertiary and Quaternary history of Antarctic seas. In Llano, G. A. (Ed.), Biology of the Antarctic Seas II. Am. Geophys. Union, Antarct. Res. Ser., 5:125-184.

1970. Stratigraphy and evolutionary trends of Radiolaria in North Pacific deep sea sediments. In Hays, J. D. (Ed.), Geological Investigations of the North Pacific. Mem. Geol. Soc. Am., 126:185-218.

Hollande, A., and Enjumet, M., 1960. Cytologie, évolution et systematique des Sphaeroidés (Radiolaires). Arch. Mus. Natl. Hist. Nat. Paris, 7:1-134.

Jørgensen, E., 1899. Protophyten und Protozoen im Plankton aus der Norwegischen Westkuste. Bergen Mus. Aarbog, 6:1-112.

1905. The protist plankton and the diatoms in bottom samples. Bergens Mus. Skr., 49-151, 195-225.

Kling, S. A., 1973. Radiolaria from the eastern North Pacific, Deep Sea Drilling Project Leg 18. In Kulm, L. D., von Huene, R., et al., Init. Repts. DSDP, 18: Washington (U.S. Govt. Printing Office), 617-671.

, 1977. Local and regional imprints on radiolarian assemblages from California coastal basin sediments. Mar. Micropaleontol., 2:207-221.

Ling, H. Y., 1973. Radiolaria: Leg 19 of the Deep Sea Drilling Project. In Creager, J. S., Scholl, D. W., et al., Init. Repts. DSDP, 19: Washington (U.S. Govt. Printing Office), 777-797.
Mast, H., 1910. Die Astrosphaeriden. Wiss. Ergebn. Dtsch. Tiefsee-Exped. "Valdivia," 19:123-190.

Müller, J., 1858. Über die Thalassicollen, Polycystinen und Acanthometren des Mittelmeeres. K. Preuss. Akad. Wiss. Berlin, Abh., 1-62.

Nakaseko, K., 1963. Neogene Cyrtoidea (Radiolaria) from the Isozaki Formation in Ibaraki Prefecture, Sci. Rep., Coll. Gen. Educ. Osaka Univ., 12:165-198.

Nigrini, C., 1970. Radiolarian assemblages in the North Pacific and their application to a study of Quaternary sediments in core V20-130. In Hays, J. D. (Ed.), Geological Investigations of the North Pacific. Mem. Geol. Soc. Am., 126:139-183.

, 1977. Tropical Cenozoic Artostrobiidae (Radiolaria). Micropaleontology, 23:241-269.

Nigrini, C. A., 1967. Radiolaria in pelagic sediments from the Indian and Atlantic Oceans. Bull. Scripps Inst. Oceanogr., 11:1-125.

, 1971. Radiolarian zonation in the Quaternary of the equatorial Pacific Ocean. In Funnell, B. M., and Riedel, W. R. (Eds.), The Micropaleontology of Oceans: Cambridge (Cambridge Univ. Press), 443-461.

, 1985. Radiolarian biostratigraphy in the central Pacific, DSDPLeg 85. In Mayer, L., Theyer, F., Thomas, E., et al., Init. Repts. DSDP, 85: Washington (U.S. Govt. Printing Office), 511-551.

Nigrini, C. A., and Lombari, G., 1984. A Guide to Miocene Radiolaria. Spec. Publ. Cushman Found. Foraminiferal Res., 22:1-320.

Nigrini, C. A., and Moore, T. C., Jr., 1979. A Guide to Modern Radiolaria. Spec. Publ. Cushman Found. Foraminiferal Res., 16:1-260.

Petrushevskaya, M. G., 1967. Radiolyarii otryadov Spumellaria i Nassellaria antarkticheskoi oblasti (Antarctic Spumelline and Nasselline radiolarians). Issled. Fauny Morei, 4:1-186. 


\section{J. C. AITCHISON}

Table 12. Radiolarians at Hole 793A.

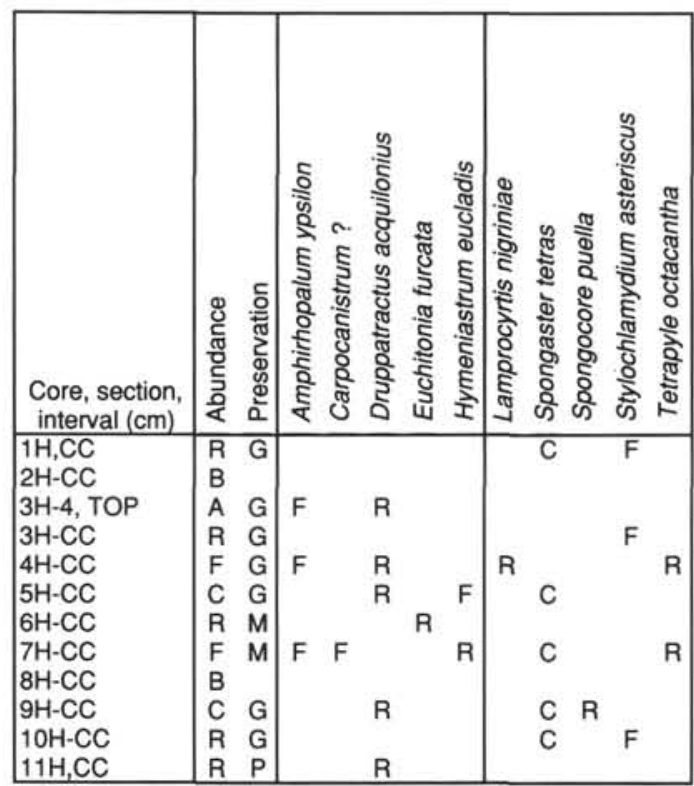

Popofsky, A., 1908. Die Radiolarien der Antarktis (mit Ausnahme der Tripyleen) (Radiolaria from the Antarctic (Tripylida excepted). Dtsch. Sudpolar-Exped., 1901-1903, 10 (Zool. Vol. 2):183-305.

Riedel, W. R., 1953. Mesozoic and late Tertiary Radiolaria of Rotti. J. Paleontol., 27:805-813.

, 1954. The age of the sediment collected at Challenger (1895) Station 225 and the distribution of Ethmodiscus rex (Rattray). Deep-Sea Res., 1:170-175.
1958. Radiolaria in Antarctic sediments. Rep. B.A.N.Z. Antarct. Res. Exped., Ser. B, 6:217-255.

1959. Oligocene and Lower Miocene Radiolaria in tropical Pacific sediments. Micropaleontology, 5:285-302.

Riedel, W. R., and Sanfilippo, A., 1970. Radiolaria, Leg 4, Deep Sea Drilling Project. In Bader, R. G., Gerard, R. D., et al., Init. Repts. DSDP, 4: Washington (U.S. Govt. Printing Office), 503-575.

1971. Cenozoic radiolaria from the western tropical Pacific, Leg 7. In Winterer, E. L., Riedel, W. R., et al., Init. Repts. DSDP, 7, Pt. 2: Washington (U.S. Govt. Printing Office), 1529-1672.

Sanfilippo, A., and Riedel, W. R., 1970. Post-Eocene "closed" theoperid radiolarians. Micropaleontology, 16:446-462.

, 1973. Cenozoic Radiolaria (exclusive of Theoperids, Artostrobids and Amphipyndacids) from the Gulf of Mexico, Deep Sea Drilling Project Leg 10. In Worzel, J. L., Bryant, W., et al., Init. Repts. DSDP, 10: Washington (U.S. Govt. Printing Office), 475-611.

1980. A revised generic and suprageneric classification of the Artiscins (Radiolaria). J. Paleontol., 54:1008-1011.

Sanfilippo, A., Westberg-Smith, M. J., and Riedel, W. R., 1985. Cenozoic radiolaria. In Bolli, H. M., Saunders, J. B., and Perch-Nielsen, K. (Eds.), Plankton Stratigraphy: Cambridge (Cambridge Univ. Press), 631-712.

Date of initial receipt: 28 November 1990

Date of acceptance: 3 June 1991

Ms 126B-140

Table 13. Radiolarians at Hole 793B.

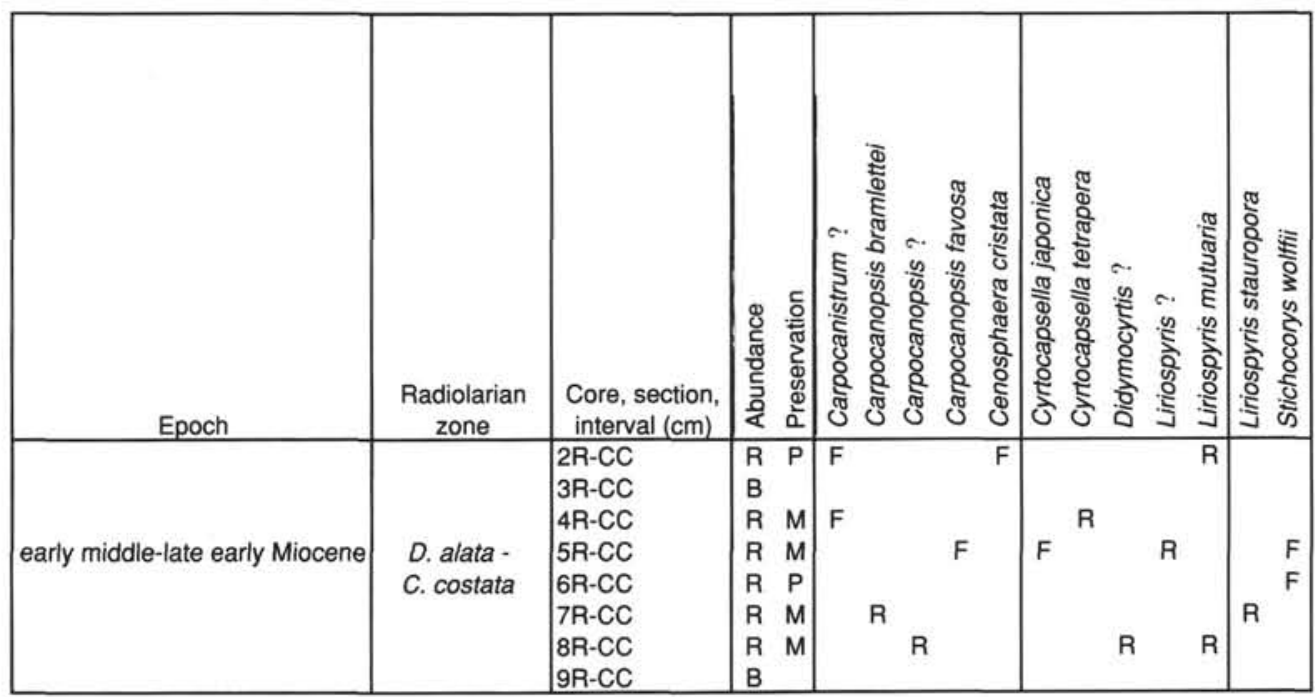

